Dariusz Kasprzak OFMCap ${ }^{1}$

ORCID: 0000-0003-0137-3514; dariusz.kasprzak@upjp2.edu.pl

Uniwersytet Papieski Jana Pawła II w Krakowie

\title{
Metafory konceptualne wyrażające wiarę w życie wieczne w tekstach reprezentatywnych ojców Kościoła zachodniego
}

\section{Streszczenie}

Analizowane $\mathrm{w}$ artykule metafory konceptualne, które wyrażają wiarę $\mathrm{w}$ życie wieczne, są oddawane jako archetypy pozytywne. Zarówno metafory przestrzenne, jak i metafory ontologiczne są wiodącymi schematami wyobrażeniowymi dotyczącymi miejsc nadprzyrodzonych czy cech tych miejsc. Rozważane metafory tworzyły uniwersalny język chrześcijański, a przez swą obrazowość angażowały wyobraźnię wiernych, wzbogacając uczuciowe reakcje czytelnika na przekaz teologiczny dotyczący tematyki nieba i wieczności.

Słowa kluczowe: metafory konceptualne, życie wieczne, ojcowie Kościoła

Abstract

Conceptual Metaphors Expressing Faith in Eternal Life in the Texts of Selected Church Fathers in the West

When working thought these texts, it was found that the conceptual metaphors used, to describe faith in eternal life, were overwhelmingly positive ones. These biblical metaphors were then developed by successive Church Fathers, which helped to create a universal Christian language. In conclusion, these eschatological conceptual metaphors, related to heaven, show the unity and progressive nature of the Christian theological Tradition.

Keywords: conceptual metaphors, eternal life, Fathers of the Church

1 Dariusz Kasprzak OFMCap - ur. 1966 roku w Krakowie, patrolog, prof. dr hab. teologii. W swych badaniach skupia się na myśli socjalnej antycznego Kościoła oraz na eschatologii i soteriologii patrystycznej. 
Język Pisma Świętego wyraża pojęcia i koncepcje zrozumiałe w kontekście kultury hebrajskiej i greckiej oraz przemawia przez wielość słownych obrazów. Te metafory kształtują zmysłowo-uczuciowe postrzeganie biblijnego przesłania². Współcześni językoznawcy kognitywni, jak Geroge Lakoff czy filozof kognitywista Marc Jonson, wskazując jak w praktyce metafory kierują ludzkim postrzeganiem, często odwołują się do pojęcia metafory konceptualnej. Ta, zwana inaczej kognitywną, zakłada pojmowanie jednej domeny w terminach innej; inaczej: to, co bardziej abstrakcyjne, wyraża się przez to, co mniej abstrakcyjne. Wyrażenia metaforyczne występujące w naszym języku codziennym odpowiadają metaforycznym procesom myślowym. Dwoma podstawowymi kategoriami metafor konceptualnych są metafory przestrzenne i metafory ontologiczne (Metafory przestrzenne są podstawowymi metaforami, gdzie punktem odniesienia jest sam człowiek, a najbardziej charakterystyczna jest tutaj orientacja pionowa. Natomiast metafory ontologiczne to metafory opierające się na rozumieniu doświadczeń pod postacią rzeczy i substancji). Potwierdzeniem tej tezy wydaje się być istnienie tych samych metafor konceptualnych w różnych językach ${ }^{3}$.

Pojęcie metafory konceptualnej wydaje się pomocne do próby opisu postrzegania eschatologicznego nieba i życia wiecznego w teologii patrystycznej, która często wykorzystywała w tym celu właśnie język metaforyczny. Podstawowymi motywami teologii biblijnej, opisującymi eschatologię końcową, są cztery metafory konceptualne: raj, niebo, wizja Boga i życie wieczne. Ich znaczenie dla teologii patrystycznej I-III wieku omówiłem już szczegółowo we wcześniejszym studium ${ }^{4}$. Natomiast $\mathrm{w}$ tym artykule pragnę wskazać na wykorzystanie powyższych metafor w patrystycznej teologii zachodniej, z koniecznymi odniesieniami

2 Por. L. Ryken, T. Longman III, J.C. Wilhoit, Niebo, w: Słownik symboliki biblijnej. Obrazy, symbole, motywy, metafory, figury stylistyczne i gatunki literackie w Piśmie Świętym, tłum. Z. Kościuk, Warszawa 2003, XV-XVI (Prymasowska Seria Biblijna, 20).

3 Zobacz: G. Lakoff, M. Johnson, Metafory w naszym życiu, tłum. T. Krzeszowski, Warszawa 1988.

4 Por. D. Kasprzak, Kształtowanie się nauki o niebie w teologii patrystycznej I-III wieku, Kraków 2017. 
do znaczącej myśli teologii scholastycznej. Po naszkicowaniu znaczenia wspomnianych metafor w teologii biblijnej, przejdę zatem do ich do omówienia w tekstach reprezentatywnych dla zagadnienia - ojców i pisarzy Kościoła zachodniego.

\section{Metafory konceptualne wyrażające wiarę w życie wieczne w teologii biblijnej}

Raj. W teologii biblijnej wskazującej na rzeczy eschatologiczne raj był przedstawiany w rozmaity sposób. Według proroków rzeczywistość, jaką Bóg stworzył dla swojego ludu miała jedynie pewne cechy pierwotnego raju: płodność, przedłużanie życia, brak śmierci, obfitość wód, pokój, pokojowe przestawanie ze zwierzętami. W apokaliptyce żydowskiej okresu międzytestamentalnego rzeczy ostateczne zostały wprost utożsamione z rajem, który zamknięty przez wieki, w czasach ostatecznych będzie otworzony ${ }^{5}$. W Nowym Testamencie termin raj ( $\left.\pi \alpha \rho \alpha ́ \delta \varepsilon 1 \sigma o \varsigma\right)$ występuje tylko trzy razy (2 Kor 12, 4; Ap 2, 7; Łk 23, 43).

Niebo. Oznacza po pierwsze to, co się widzi, kiedy podnosi się wzrok ku górze. W takim postrzeganiu na niebie widzi się chmury, słońce, księżyc, planety, gwiazdy. W drugim znaczeniu, bardziej koncepcyjnym, niebo jest pojmowane idealistycznie, ponieważ jest obecnie nieosiągalne, i jako takie jest granicą wszystkiego, co teraźniejsze, jest wydzieloną częścią nieba, rodzajem powłoki z atmosfery, gwiazd, planet i ziemi Augustyn Jankowski zaznaczył, że u podstaw wielu takich wypowiedzi Starego Testamentu o niebie leży starożytny, przednaukowy obraz świata, a po zinterpretowaniu tych obrazowych odniesień biblijne niebo oznacza Bożą sferę, gdzie z Bogiem przebywają aniołowie i święci ludzie. Samo pojęcie sfera jest tutaj także tylko próbą wniknięcia w misterium przy pomocy pojęć nam dostępnych ${ }^{8}$.

5 Por. H. Vorgrimler, Geschichte des Paradies und des Himmels. Mit einem Exkurs über Utopie, München 2008, s. 13-27.

6 Por. M. Schmaus, Das Paradies, München 1965, s. 8-11.

7 Por. X.L. Dufour, Wniebowstapienie, w: Słownik teologii biblijnej, tłum. K. Romaniuk, Poznań 1990, s. 1054.

8 Por. A. Jankowski, Eschatologia Nowego Testamentu, Kraków 2007, s. 143. 
„Wizja Boga” nazywana też „wizją błogosławioną” lub „uszczęśliwiającą" to przenośnia bliska antycznej obrazowości greckiej, gdzie postrzeganie świata i jego opis dokonywał się w sposób szczególny za pomocą zmysłu widzenia. Warto podkreślić, że samo utożsamianie „widzieć” i „wiedzieć” jest przedgreckie, co można odnieść do indoeuropejskiego rdzenia: „wid-”, np. w języku polskim jest obecne w słowach: widzieć i wiedzieć 9 . Stary Testament z jednej strony podkreśla niemożność zobaczenia przez człowieka istoty Boga, z drugiej - teksty biblijne Starego Testamentu wyrażają ciągłe pragnienie ujrzenia Boga. Autorzy Nowego Testamentu, szczególnie św. Jan w swoich tekstach akcentuje prawdę, że Boga można widzieć przez wiarę, z jaką spotyka się Jezusa Chrystusa. Jak zauważył Juan Luis Ruiz de la Peňa, w refleksji teologicznej Zachodu bardziej podkreślano w wizji Boga element poznawczo-intelektualny (np. $\theta \varepsilon \omega p i ́ \alpha$, kontemplacja $)^{10}$. Tezę tę od XIII-wiecznej scholastyki głosi dziś np. współczesny tomizm ${ }^{11}$. Dlatego Karl Rahner postulował podczas stosowania tego terminu łączenie elementu intelektualno-poznawczego $\mathrm{z}$ aspektem relacyjnym ${ }^{12}$.

Życie wieczne. Ewangeliczny zwrot „życie wieczne” oznacza życie wieczne w przyszłym eonie, życie, które pochodzi z oczekiwanego zmartwychwstania umarłych ${ }^{13}$. Można powiedzieć, iż w teologii nowotestamentalnej są obecne trzy koncepcje wieczności: (1) wieczność nieograniczona, (2) wieczność ograniczona i (3) życie wieczne. Teologiczny przekaz Biblii wiąże wszelkie życie i jego jakość wyłącznie z Bogiem. Człowiek nie posiada życia sam z siebie, ale jako jedno ze stworzeń

9 Por. É. Benveniste, Il vocabolario delle istituzioni inodoeuropee, vol. 2: Potere, diritto, religione, Torino 1981, s. 414-415 (Nuova Biblioteca Scientifica Einaudi, 55bis).

10 Por. J.L. Ruiz de la Peňa, L'altra dimensione, Roma 1981, s. 237.

11 Por. M.A. Krąpiec, Z.J. Zdybicka, Świętość spełnieniem osoby, w: Człowiek - kultura - uniwersytet, red. M.A. Krąpiec, Lublin 1982, s. 73-74.

12 Por. K. Rahner, Visio beatifica, w: Enciclopedia teologica. Sacramentum mundi, vol. 8, ed. K. Rahner, Brescia 1977, s. 637.

13 Por. R. Pesch, Il vangelo di Marco. Parte seconda. Testo e traduzione. Commento ai capp. 8,27-16,20, Brescia 1982, s. 215 (Commentario teologico del Nuovo Testamento, II/2); S.E. Porter, Wieczność, wieczny, w: R.P. Martin, P.H. Davids, Słownik późnych ksiąg Nowego Testamentu i pism Ojców apostolskich, tłum. zbiorowe, Warszawa 2014, s. 1064 (Prymasowska Seria Biblijna, 39). 
Bożych został obdarowany życiem przez Boga. Obecne życie ludzkie jest kruche, ale święte. Bóg obiecuje swym stworzeniom ciągłość życia, bo to Bóg jest źródłem życia ${ }^{14}$.

\section{Metafory konceptualne wyrażające wiarę w życie wieczne w teologii reprezentatywnych ojców Kościoła zachodniego}

Sposób pojmowania takich metafor konceptualnych przez zachodnich pisarzy i ojców Kościoła scharakteryzuję w odniesieniu do tekstów najbardziej znaczących autorów, którzy dokonali oryginalnego wkładu w rozwój zachodniej myśli eschatologicznej. Skoncentruję się na myśli zachodnich autorów patrystycznych, ale dokonam również koniecznego rozwinięcia dotyczącego zastosowania analizowanych metafor konceptualnych w teologii średniowiecznej.

Raj. Jest pierwszą biblijną metaforą przestrzenną, za pomocą której autorzy natchnieni starali się oddać obraz eschatologii jako miejsca. To wyobrażenie biblijne, podobnie jak druga biblijna metafora przestrzenna - niebo, ze względu na swoją prostotę zostało szybko przyjęte w judaizmie i chrześcijaństwie. Jak zauważył Antonio Nitriola, obie wspomniane metafory przestrzenne przynależą do języka zwyczajowego, katechetycznego i codziennego ${ }^{15}$.

Pierwszym z ojców Kościoła, który znacząco wykorzystał tematykę raju jako swoistego przedpokoju do właściwej rzeczywistości eschatologicznej w sensie eschatologii końcowej, był Ireneusz z Lyonu ${ }^{16}$. Koncepcja raju ziemskiego, otworzonego na nowo dla ludzi i pojmowanego jako miejsce eschatologicznej szczęśliwości dla sprawiedliwych rozwinęła się

14 Por. J. Barr, Biblical Words for Time, London 1962 (Studies in Biblical Theology, 33); A.-M. Dubarle, Oczekiwanie nieśmiertelności w Starym Testamencie i w judaizmie, tłum. E. Szewc, „Concilium. Wydanie Polskie” 6-10 (1970), s. 214-222.

15 Por. A. Nitrola, Trattato di escatologia, vol. 2: Pensare la venuta del Signore, Cinisello Balsamo 2010, s. 409.

16 Por. Irenaeus Lugdunensis, Adversus Haereses V,5,1, Hrsg. N. Brox, Freiburg im Breisgau 2001, s. 50-52 (Fontes Christiani, 8/5). Więcej na ten temat zobacz: W. Myszor, Millenaryzm w ujęciu Ireneusza z Lyonu, „Tarnowskie Studia Teologiczne” 19 (2000) z. 1, s. 27-38. 
szczególnie w millenaryzmie żydowskim i chrześcijańskim ${ }^{17}$. Późniejsi zachodni teologowie III wieku, w większości millenaryści, jak Tertulian z Kartaginy, Laktancjusz, Wiktoryn z Petovium czy niebędący millenarystą Cyprian z Kartaginy, zgodnie jednak uznawali, że po zburzeniu świata doczesnego, nastąpi sąd ostateczny i wyznaczenie ludziom ostatecznej nagrody lub kary za ich uczynki. Według tych autorów eschatologiczne niebo posiadałoby cechy „uczty” bądź „raju”, byłoby najczęściej pojmowane jako rzeczywistość materialna, miejsce wymiernej „nagrody” $\mathrm{i}$,wytchnienia / odpoczynku” ${ }^{18}$.

Metaforę przestrzenną raju eschatologicznego w teologii chrześcijańskiej zaczęto rozumieć jako prawdę, że Bóg w określonym momencie historii człowieka pragnął go najpierw obdarzyć udziałem w swojej wspaniałości, odczuwalnym jako rozkosz. Tak pojmowany raj byłby zatem miejscem idealnym, stworzonym przez Boga, miejscem stanowiącym pierwszy krok Boga idącego ku człowiekowi, aby go wprowadzić w eschatologię końcową ${ }^{19}$.

Niebo w koncepcjach ojców i pisarzy zachodnich II i III wieku powtarzało w swej figuratywności starożytny, przednaukowy obraz świata zawarty w Starym Testamencie (sklepienie niebieskie/firmament; najwyższa część stworzenia; miejsce zamieszkania istot niebiańskich: zwierząt i aniołów) czy też w Nowym Testamencie (helleńska mitologia Hermas w Arkadii oraz kosmologia dwóch lub trzech części składowych uniwersum). W teologicznej interpretacji tych obrazowych odniesień biblijnych niebo oznaczało zawsze sferę Bożą, nakierowywało na Boga,

17 Por. D. Kasprzak, Milenaryzm: „ziemski raj” tylko dla wybranych sprawiedliwych - okres patrystyczny, w: W oczekiwaniu na Królestwo. Nadzieje i obawy związane z końcem tysiaclecia, red. P.J. Śliwiński, Kraków 2000, s. 89-124; H. Pietras. Millenaryzm a interpretacja szabatu (I-II w.), „Tarnowskie Studia Teologiczne” 19 (2000) z. 1, s. 9-25.

18 Por. M. Wysocki, Eschatologia okresu prześladowań na podstawie pism Tertuliana i Cypriana, Lublin 2010, s. 167-228; J. Wojtczak, Eschatologiczne koncepcje Laktancjusza w VII księdze „Divinae Institutiones”, „Vox Patrum” 19 (1990), s. 609-620; D. Kasprzak, Drugi millenaryzm w ujęciu Wiktoryna z Poetovium, w: Między Biblia a kulturą, red. T. Jelonek, R. Bogacz, Kraków 2011, s. 43-57 (Biblia w Kulturze Świata, 2).

19 Por. E. Haag, Der Mensch am Anfang. Die alttestamentliche Paradiesvorstellung nach Gn 2-3, Trier 1970, s. 27; S. Kobielus, Człowiek i ogród rajski w kulturze religijnej średniowiecza, Warszawa 1977, s. 134. 
gdzie z Bogiem przebywają ludzie święci i aniołowie. Najczęściej stosowaną metaforą sfery Bożej było wyobrażenie królestwa Bożego, w tym jego szczególny aspekt: królestwo Ojca. W niektórych tekstach (Homilia z II w. 12, 1-6; czy Agrafa 8 u Psuedo Klemensa Rzymskiego) napotykamy na wątek androgynii jako warunek wejścia do królestwa Bożego (tematyka typowa dla apokryficznych ewangelii II wieku: np. Ewangelia Tomasza; Ewangelia wg Egipcjan). Królestwo Boże jako niebo nabiera też cech miasta (Hermas, Pasterz: czworokątna wieża, mur, jedna brama), właściwości apokaliptycznych (Hermas, Pasterz: kolor biały jako kolor wybranych Pana). Niebo pojmowane jako królestwo Ojca to temat typowy dla millenarystów. Królestwo millenijne Syna stanowiłoby etap przygotowawczy do wejścia do królestwa Ojca po zakończeniu drugiego millenium (Ireneusz, Adversus haereses 36, 3: najpierw / następnie). Ci zbawieni, którzy zostaną włączeni do Jerozolimy niebieskiej, kiedy ta zstąpi z nieba na ziemię, tak jak i samo miasto, uzyskają cechy już nie anielskie (te były w królestwie millenijnym Chrystusa), ale boskie, zamieszka w nich Duch, staną się równi Bogu (Adversus haereses 5, 36, 1-3), obdarzeni nieśmiertelnością (Adversus haereses 5, 36, 1-3). Tertulian (Przeciw Marcjonowi 3, 24, 5) i Wiktoryn (In Apocalipsin 3, 4, 1) mocno podkreślali aspekt nieba jako wymiernej nagrody dla sprawiedliwych, prawdopodobnie zróżnicowanej według zasług moralnych (Tertulian, Przeciw Marcjonowi 3, 24, 6; Cyprian, Laktancjusz, Divinae Institutiones 7). Wiktoryn niebo utożsamiał ze stanami Ducha Bożego, ale także z samym Chrystusem, do którego te stany odnosił ${ }^{20}$.

Niebo, jako kolejna metafora przestrzenna w tekstach pisarzy i ojców Kościoła zachodniego, stało się w związku z tym nie tylko odniesieniem do rzeczywistości kosmologicznej, ale przede wszystkim było rozważane w perspektywie teologicznej, jako sposób bądź miejsce istnienia Boga. Co więcej, metafora nieba była rozważana w ujęciu soteriologicznym: w niebie dopełni się panowanie Boga, ludzie zbawieni wejdą w pełną relację z Bogiem i osiągną szczęście. Tak pojmowane niebo było rozumiane

20 Por. D. Kasprzak, Ksztattowanie się nauki o niebie w teologii patrystycznej I-III wieku, s. $300-320$. 
jako wspólnota z Chrystusem, ze świętymi, jako nagroda, wieczna uczta, doskonałe miasto.

Widzenie. Grecki sposób postrzegania „widzenia” i „wiedzenia” o Bogu znajdujemy już u Teofila z Antiochii ${ }^{21}$ czy Klemensa Aleksandryjskiego ${ }^{22}$. Według tego ostatniego wizja twarzą $\mathrm{w}$ twarz, jakiej dozna w wieczności gnostyk, czyli szczęśliwy, będzie ciągłym zgłębianiem niezgłębionego Boga, ciągłym zanurzaniem się w Jego misterium.

W teologii Kościoła zachodniego teologię wizji Boga najpełniej opracował w antyku chrześcijańskim Augustyn z Hippony. Biskup Hippo Regius od ojców greckich przejął dziedzictwo platońskie, lecz zmodyfikował ów helleński sposób utożsamiania „widzenia i wiedzenia” i nadał mu własną interpretację $e^{23}$. Przez Augustyna mądrość była pojmowana jako poznanie intelektualne rzeczy wiecznych ${ }^{24}$, jako taka stanowiła prawdziwą szczęśliwość, a zarazem była poszukiwaniem szczęśliwości ${ }^{25}$. Ponieważ przedmiotem tak rozumianej mądrości jest wyłącznie Bóg (por. De Trinitate 12,14, 22), całe ujęcie poznawcze uzyskuje u Augustyna dynamikę eschatologiczną, w której poszukiwanie szczęśliwości w doczesności i w wieczności to dwa etapy osiągania szczęścia: etap drogi i etap mety $^{26}$.

Etap ziemski to okres, w którym Boga nikt nigdy nie widział, ponieważ Bóg jest ze swej natury niewidzialny i niezmienny, objawia się temu, komu chce, pod postacią, jaką chce. Jego niewidzialna i niezmienna

${ }^{21}$ Por. Teophilus Antiochenus, Ad Autolycum 1, 2 - 2, 6, tłum. L. Misiarczyk, Kraków 2004, s. 385 (BOK 24).

22 Por. Clemens Alexandrinus, Stromata 1, 19, 94, 6, Paris 1951 (Sources Chrétiennes [dalej: SCh] 30); tłum. polskie: Klemens Aleksandryjski, Kobierce zapiskow filozoficznych dotyczacych prawdziwej wiedzy, t. 1, tłum. J. Niemirska-Pliszczyńska, Warszawa 1994, s. 69; Clemens Alexandrinus, Stromata 5, 1, 7, 6-7; 5, 11, 71, 3-4; tłum. polskie: Klemens Aleksandryjski, Kobierce, t. 1-2, 10, 58.

${ }_{23}$ Por. Ch. Trottmann, La vision béatifique des disputes scolastiques à sa définition par Benô XII, Rome 1995, s. 54.

24 Por. Aurelius Augustinus, De Trinitate 12, 15, 25, tłum. M. Stokowska, Kraków 1996, s. 378-379 (Biblioteka Filozofii Religii, 30), powołując się na 1 Kor 12 rozróżnia pomiędzy mądrością a wiedzą. Mądrość przynależy do poznania intelektualnego rzeczy wiecznych, natomiast wiedza rozumowa - do rzeczy czasowych.

25 Por. É. Gilson, Introduzione allo studio di Sant'Agostino, Genova-Milano 2014, s. 15.

26 Por. A. Nitrola, Trattato di escatologia 2, s. 439-444. 
natura ciągle pozostaje w Nim integralna („eius invisibilis incommutabilisque natura", Epistula 147, 8, 20). Augustyn powołując się na Wj 33,20 („nikt nie może zobaczyć Boga i pozostać żywy”) argumentuje, że nikomu z ludzi na ziemi nie została przyznana łaska oglądania natury Boga. Paweł oglądał Boga jedynie w jego przejawach / manifestacjach, ale nie w Jego naturze (Epistula 147, 13, 31). Z drugiej strony pragnieniem człowieka pobożnego jest widzenie Boga nie w przejawach (in specie), bo w tych objawia się On każdemu na różne sposoby, ale zobaczenie tej natury, dzięki której jest On tym, kim jest (,in eam substantiam, qua ipse est quod est", Epistola 147, 8, 20). Augustyn powołując się na 1 J 3, 2, stwierdza, że widzenie Boga w jego naturze dokona się dopiero w wieczności, kiedy ludzie będą podobni do Boga (Epistula 147, 8, 20).

Augustyn wychodząc od tekstu 1 Kor 13, 12 stwierdzał, że w doczesności wierzący mogą oglądać Boga w wizji sub species: jak w zwierciadle (per speculum) i niejasno (in aenigmate). Według retoryki Augustyna zwierciadło oznacza obraz, a enigma podobieństwo (De Trinitate 15, 9, 16). W doczesności perspektywą widzenia pozostaje natura ludzka (,,jesteśmy zmuszeni, aby rozpoczynać od tego wyobrażenia (imago), jakim sami jesteśmy, do widzenia w jakiś sposób, jakby w zwierciadle, tego który nas stworzył” (De Trinitate 15, 8, 14), człowiek ,jeśli jest podobieństwem [Boga], to oczywiście jest i Jego chwałą" (por. 1 Kor 11, 7) - De Trinitate $15,8,14$, ale ciągle poznaje poprzez zamazaną, niewyraźną perspektywę obrazu, dlatego tak wielu ludzi nie widzi Boga w doczesności. Na etapie drogi, od doczesności do zmartwychwstania, Augustyn zdaje się wyróżniać trzy stadia: początek w doczesności, stan pośredni do sądu ostatecznego ${ }^{27}$ oraz stadium podczas zmartwychwstania. Początek tej drogi rodzi się z nadziei szczęścia / błogosławieństwa, jakie żywi dusza wierzącego. Życie ziemskie duszy jest jednak okresem mrocznym, niedopełnionym. Drugi etap tej drogi to stan duszy oddzielonej od ciała. Trzeci to doskonała szczęśliwość duszy podczas zmartwychwstania ciała.

W wieczności zobaczymy Boga twarzą w twarz (facie ad faciem), bo owa enigmatyczność poznawania zniknie, nawet jeśli ludzkie poznanie będzie

27 Stan ten opisuje Augustyn szczególnie w: Aurelius Augustinus, De Genesi ad litteram imperfecus liber 12, s. 32-35. 
podobne do tego boskiego (De Trinitate 15, 16, 26). Dopiero w wieczności wierzący zbawieni będą mogli oglądać Boga, jakim jest („sicuti est”). W stanie pośrednim dusze będą miały ogląd Boga jedynie w sposób niedoskonały. Dopiero kompletny człowiek zmartwychwstały w ciele dostąpi doskonałego oglądu Boga. Jednak także i ten ogląd Boga przez zbawionych po zmartwychwstaniu nie będzie wizją absolutnie doskonałą, ale względnie doskonałą: wszyscy zbawieni będą ludźmi czystego serca (Civitas Dei 22, 29, 4; Epistola 147, 10, 23), co zdaniem Augustyna stanowi warunek osiągniecia wizji Boga takim, jakim jest (,sicut est” Epistola 147, 20, 48 ${ }^{28}$.

Augustyn w swoich późniejszych traktatach opisuje wizję uszczęśliwiającą jako bezpośrednie widzenie Boga i zasiadanie po Jego prawicy, widzenie Boga przez oczy zmartwychwstałego i uwielbionego ciała, widzenie Go jako Ojca, Syna i Ducha Świętego. Wizja uszczęśliwiająca ma charakter dynamicznego postrzegania, stanowi cudowną fuzję rozumienia i miłości. Augustyn opisuje ową wizję, używając języka metaforycznego: serce człowieka będzie spokojne tylko w Bogu (Confesiones 1,1), Bóg jest źródłem i spełnieniem naszych pragnień (Civitate Dei 10,3), w niebie pozostaniemy i będziemy widzieli, widzieli i kochali, kochali i modlili się (Civitate Dei 22, 30), niebo będzie całkowitym spełnieniem się rozumienia (intellegere; videre) i szczęścia (frui; gaudere) - De Trinitate 8, 3-10 $0^{29}$. W Augustynowej teologii wizji możemy też mówić o duchowości wizji. Wypracowywanie wizji uszczęśliwiającej zaczyna się według Augustyna już na ziemi: jako pragnienie serc wierzących; duchowe szukanie oblicza Bożego; praktykowanie błogosławieństw; „twarzą serca”; uciekanie od antropomorfizacji Boga, a mierzenie Go cnotami - w sercu przez wiarę ${ }^{30}$.

Myśl Augustyna o tym, że zbawieni będą się cieszyć w niebie wizją natury Boga (in natura), a nie jedynie powierzchownie - wizją Jego splendoru (in claritate) powtórzył następnie Grzegorz Wielki, wychodząc

28 Por. A. Nitrola, Trattato di escatologia 2, s. 439-444.

${ }_{29}$ Por. J.B. Russell, Heaven, Paradise, w: Augustine through the Ages. An Encyclopedia, ed. A.D. Fitzgerald, Grand Rapids (Michigan) 1999, s. 420.

30 Por. Aurelius Augustinus, Sermo 53,6, tłum. J. Jaworski, Warszawa 1973, s. 337-339 (Pisma Starochrześcijańskich Pisarzy [dalej: PSP], 12). 
z założenia, że prosta i niezmierzona esencja Boża nie jest z jednej strony splendorem, a z drugiej naturą, „lecz sama Jego natura jest blaskiem, a sam blask Jego naturą” (,ipsa ei natura sua clariate, ispa claritas natura est" ${ }^{31}$ ). Grzegorz dokonał też decydującego rozgraniczenia pomiędzy widzeniem esencji bożej i widzeniem w sposób pełny tejże esencji:

\begin{abstract}
Wszechmogącego odnajdziemy kiedyś w jawnym poznaniu, gdy wzgardzimy do szczętu zepsuciem naszej śmiertelności i ujrzymy Go, wyniesieni do nieba, w blasku Jego bóstwa. Teraz natomiast łaska wylanego Ducha odrywa umysł od cielesnego myślenia i wzniosi go ku wzgardzeniu przemijającymi rzeczami. Umysł lekceważy wszystko, czego pożądał spośród rzeczy przyziemnych i rozpala się ku najwyższym pragnieniom. Siła kontemplacji wznosi się poza ciało, choć ciężar skażenia trzyma go jeszcze w ciele. Usiłuje poznać blask niezmiernej światłości, lecz nie potrafi. Duch, uciskany słabością, nie może jej przeniknąć, lecz nawet odpychany, miłuje ją. Już bowiem Bóg okazał, za co należy Go miłować, lecz ukrywa przed kochającymi swój widok i obraz. Kroczymy więc, dostrzegając jedynie Jego ślady i dzięki znakom Jego darów podążamy za Tym, którego jeszcze nie widzimy. [...] Wszechmogącego natomiast można poznać w kontemplacji obrazu (per contemplationis speciem), otrzymując najwyższą nagrodę; ale nie można Go poznać doskonale (ad perfectum), bo nawet jeśli Go wreszcie widzimy w Jego jasności (in claritate sua), nie pojmujemy w pełni (plene) Jego istoty (eius essentiam). Gdy bowiem umysł ludzki lub anielski dąży do nieograniczonej Światłości, podlega ograniczeniu na mocy samego faktu, że jest stworzeniem; próbuje nawet wznieść się ponad siebie, lecz nawet tak wytężony nie potrafi ogarnąć Jego blasku; On bowiem przenikając, podtrzymując i napełniając wszystko, wszystko w sobie zawiera ${ }^{32}$.
\end{abstract}

Zdaniem Grzegorza Wielkiego w wieczności Bóg będzie oglądany wedle Jego natury, takim jaki jest (sicuti est), ponieważ zbawieni poznają Jego esencję, która jednak nie zostanie poznana doskonale czy w pełni ${ }^{33}$. Syntezę patrystycznego i średniowiecznego nauczania dotyczącego wizji uszczęśliwiającej zawierają dwa dokumenty: konstytucja Benedictus Deus Benedykta XII (1336 r.) i bulla dogmatyczna Laetentur caeli Soboru

31 Por. Gregorius Magnus, Moralia sive Expositio in Iob 18, 54, 90, wersja polska: Grzegorz Wielki, Moralia: komentarz do Księgi Hioba, t. 4, Księgi XVII-XXII, tłum. E. Buszewicz, A. Wilczyński, Kraków 2013, s. 159 (Źródła Monastyczne, 63).

32 Gregorius Magnus, Moralia sive Expositio in Iob, 10, 8. 13, wersja polska: Grzegorz Wielki, Moralia sive. Komentarz do Księgi Hioba, t. 2, tłum. K. Nastał, E. Buszewicz i in., Kraków 2006, s. 367 (Źródła Monastyczne, 41).

33 Por. G. Cremascoli, Novissima hominis nei Dialogi di Gregorio Magno, Bologna 1979, s. $119-129$. 
Florenckiego (1439 r.). Podstawę do tej syntezy zachodniej teologii dał Jan Szkot Eriugena (810-877), który próbował pogodzić teologię wizji Augustyna ze wschodnią koncepcją nieba według Pseudo Dionizego Areopagity w teorii kontemplacji Bożych teofanii i w ten sposób przesunął dyskusję w stronę ubóstwienia ludzkiej natury, a tym samym na nowo rozpoczął dyskusję dotyczącą wizji uszczęśliwiającej. Aleksander z Hales (1183-1245) zastosował podział widzenia esencji (essentiam) Boga: per se, per speciem, per similitudinem (pierwszą ma tylko Bóg; człowiek dwie pozostałe, w których widzi Boga takim, jaki jest (sicut est), ale nie w sposób pełny (plene). Natomiast wraz z potępieniem przez biskupa Paryża Juliana z Alwernii tez Étienne'a de Venisy zrodzi się kwestia: czy wizja uszczęśliwiająca oznacza poznanie „czym Bóg jest (quid est Deus)”? Według Tomasza z Akwinu wizja odpowiada szczęśliwości (beatitudo), a najwyższa i doskonała szczęśliwość to wizja Bożej esencji. Jest ona natychmiastowa i pośrednia zarazem (światło, które ma udział w świetle Bożym; wizja per similitudinem). Taka wizja nie jest zrozumieniem Boga (bo rozumie się jedynie to, co jest doskonale znane), a poza tym wizja esencji Boga będzie różna w zależności od stopnia miłości. Rozwiązanie Tomasza stało się dominujące w Kościele na wieki. Ponadto utrzymały się także dwie frakcje teologiczne: dominikańska i franciszkańska. Pierwsza - za Tomaszem - uznawała, że w momencie zmartwychwstania nastąpi w człowieku ekstensywny (extensive) wzrost szczęśliwości (od doskonałości do jeszcze większej doskonałości). Natomiast teolodzy franciszkańscy - idąc za Augustynem - głosili, że wraz ze zmartwychwstaniem nastąpi w człowieku intensywny (intensive) wzrost szczęśliwości (od niedoskonałości do doskonałości).

Po serii wątpliwości, jakie wystąpiły po nauczaniu papieża Jana XXII w sprawie wizji uszczęśliwiającej, kolejny papież Benedykt XII wydał 29 stycznia 1336 roku konstytucję Benedictus Deus (DS 1000-1001). Stwierdzał w niej, że wszyscy, którzy po śmierci są święci, nie mają nic do oczyszczenia lub przeszli już oczyszczenie. Po męce i śmierci Jezusa Chrystusa widzieli i widzą naturę/esencję Bożą („viderunt et vident divinam essentiam”) w wizji intuitywnej, twarzą w twarz (,visione intuitiva et etiam faciali"), bez pośrednictwa jakiegoś przedmiotu czy pośrednictwa stworzeń („,nulla mediante creatura in ratione obiecti visi 
se habente"). Zostanie im objawiona natura/esencja Boska w sposób natychmiastowy, otwarty, jasny i jawny („divina essentia immediate a se nude, clare et aperte eis ostendente"). Stanowisko teologiczne z konstytucji Benedictus Deus zostało następnie powtórzone przez nauczanie Soboru Florenckiego z 1439 w bulli Laetentur caeli, z dwoma precyzacjami: zastąpieniem terminu „videre” przez termin ,intueri” oraz oświadczeniem, że wizja będzie dotyczyła Boga w Trójcy jedynego (,intueri clare ipsum Deum trinum et unum, sicut est"). Te dwie średniowieczne bulle ustalają nauczanie dogmatyczne dotyczące wizji uszczęśliwiającej, praktycznie do XX wieku ${ }^{34}$.

Wladimir Lossky zaznaczył, że mówiąc w eschatologii o poznaniu /

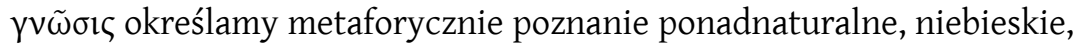
kiedy stosujemy wyrażenia: oświecony „światłem niebieskim” czy „poznając ponadintelektualnie”. Istnieje zatem nasze wymierne poznawanie i poznawanie opisywane w sensie metaforycznym, nie tylko przez analogię (bo i ta jest niewystarczająca) dla opisu rzeczy ostatecznych. To nie język opisowy, nie ściśle analogiczny, ale właśnie metaforyczny przezwycięża pokusę, że jesteśmy w stanie wszystko pojąć i zdefiniować, typową dla teologii wyłącznie intelektualnej. Przywiązani do schematu dyskursu analogiczności nie zdołamy oddać niepojmowalności Boga. Dlatego potrzeba metafory jako żywego języka, który nie zamyka, lecz otwiera, który odwołuje się zawsze do kolejnego słowa i w ten sposób relatywizuje każde ujęcie wyczerpujące każdy system, każdą analogię $e^{35}$. Antonio Nitriola wskazuje, że definicje dogmatyczne antyku czy średniowiecza są obciążone bagażem koncepcji i systemów, które chociaż wyrażają się przez metafory, często są metaforami nieuświadomionymi. Dlatego odczytując je dzisiaj musimy zdawać sobie sprawę z różnicy dyskursu analogicznego i opisów metaforycznych. W eschatologii Tomasza z Akwinu wizja uszczęśliwiająca odpowiada realizacji naturalnego pragnienia („desiderium naturale”) widzenia Boga (O księgach Fizyki Arystotelesa 8,15,7), czyli odwołuje się do czegoś wspólnego w świecie. Akwinata

34 Por. C. Naumowicz, Konstytucja Benedykta XII „Benedictus Deus”. Próba nowego spojrzenia na kontrowersje, „Teologia w Polsce” 4 (2010) nr 1, s. 109-123.

35 Por. V. Lossky, Vision de Dieu, Paris 1962, s. 133. 
podobnie myśli, kiedy mówi o zróżnicowanych stopniach wizji w niebie, czego echo znajdujemy w bulii Laetentur caeli (DH 1305). Można zawsze zadać pytanie: jak to możliwe, że dogmat chce oznajmić rozdzielenie przyszłych wizji według doczesnych zasług. Bo sama wizja jest opisywana metaforycznie, aby oddać komunię pomiędzy Bogiem a człowiekiem, jaka dokona się w wieczności. Jednak ten konkretny dogmat nie opisuje tego ekskluzywnie, zostawiając przestrzeń do pogłębionej, dalszej refleksji. Wydaje się, że Tomasz w przesłaniu Sumy teologicznej nie ma odpowiednich narzędzi teologicznych, aby pójść dalej. Takie metaforyczne narzędzia zdaje się natomiast posiadać Grzegorz Palamas. Każdy ekskluzywizm (systemowy, metaforyczny) niesie zagrożenie. Możemy bowiem zagubić metaforyczność, zapominając, że mówimy o eschatonie, albo zagubimy dogmat, kiedy zapomnimy o logice katolickiej w teologii. Stąd powstrzymanie zarozumiałości systemów teologicznych nie oznacza też popadnięcia w kolejne słowa, które inaczej będą mówiły o eschatonie ${ }^{36}$.

\section{4. Życie wieczne}

W wyznaniach wiary w języku greckim artykuł o życiu wiecznym wy-

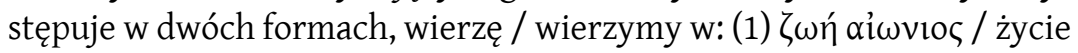
wieczne (Symbol Cyryla Jerozolimskiego, Enchiridion symbolorum, definitionum et declarationum de rebus fidei et morum, ed. H. Denzinger, P. Hünermann, (Freiburg 1991) Bologna 1995 (dalej: DH), 41; Symbol Epifaniusza z Salaminy - forma dłuższa, DH 44; Interpretacja symbolu pseudo-atanazjańskiego, DH 46; Wielki symbol Kościoła armeńskiego, DH 48; Symbol chrzciel-

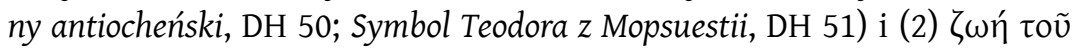

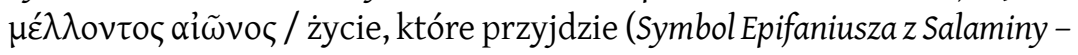
forma krótsza, DH 42; Konstytucje apostolskie, DH 60; Symbol konstantynopolitański, DH 150). W wyznaniach wiary w języku łacińskim występuje jedna forma: (credo / crediamo) vita eterna (Symbol apostolski, DH 30; Sakramentarz gelaziański, DH 36; Fides Damasi, DH 30; Symbol pseudo-atanazjański „Quicumque”, DH 76). We wszystkich aktach wyznań wiary można zaobserwować charakterystyczne następstwo: najpierw wyznanie wiary w zmartwychwstanie umarłych, po którym następuje wyznanie wiary

36 Por. A. Nitrola, Trattato di escatologia 2, s. 462-471. 
w życie wieczne; lub następstwo typu: najpierw wyznanie wiary w zmartwychwstanie umarłych, następnie w sąd, a na końcu w życie wieczne. Daje się tutaj wychwycić oryginalną perspektywę apokaliptyczną, że życie wieczne, jakiego się oczekuje, następuje po zmartwychwstaniu ciał. Stąd wniosek, że będzie to życie inne, nie podporządkowane śmierci, podobnie jak życie Boże. Formy aîuvos i eaterna są tłumaczone jako „wieczne”. Tę nadchodzącą rzeczywistość przyszłych rzeczy określamy też formą od rzeczownika: aíuv i aeternitas, czyli „wieczność” ${ }^{37}$.

W historii teologii pierwszym istotnym ze względu na treść, jak i metodę rozważaniem o wieczności była myśl Augustyna z Hippony ${ }^{38}$. Aeternitas i tempus u Augustyna są świadectwem różnicy, jaka jest pomiędzy Bogiem a człowiekiem, Stworzycielem a stworzeniem. Wieczność ma kategorię niezmienności, natomiast czas jest określany jako znak (signum) lub ślad (vestigium) wieczności ${ }^{39}$. Augustyn uznaje ujęcie platońskie o tzw. możliwości ostatniego trwania, owego trzeciego tajemniczego trwania „aevum”, o którym Platon mówił w Timajosie i sygnalizuje to, kiedy komentuje Tt $1,2^{40}$.

Aevum platońskie było jednak dla Augustyna pewnym poboczem rozważań, gdyż zasadniczą kwestię stanowiło przeciwstawienie wieczności stworzeniu. Ta kwestia zostaje przez Augustyna rozwiązana, kiedy mówi o szczęśliwości wiecznej w mieście Bożym ${ }^{41}$. Zbawieni zostaną tam obdarzeni nieśmiertelnością i anielskością („tam dostąpią tego, czego aniołowie święci nie utracili nigdy”). Ciało zbawionych „zamienione zostanie $\mathrm{z}$ dawnego ciała cielesnego (animalis) w nowe uduchowione (spiritalis)

37 Por. A. Nitrola, Trattato di escatologia 2, s. 471.

38 Por. J. Guitton, Le temps et l'éternité chez Plotin et Saint Augustin, Paris 2004, s. 197-198.

39 Aurelius Augustinus, De Genesi ad litteram imperfecus liber 13, 38: „...wraz z odmiennością upływu czasu oznacza ponad nimi niezmiennie trwałą wieczność, ażeby czas przedstawiał się jakby znak (signum) i ślad wieczności (quasi vestigium aeternitatis)" (św. Augustyn, Pisma egzegetyczne przeciw manichejczykom (Przeciwko manichejczykom komentarz do Księgi Rodzaju, Niedokończony komentarz słowny do Księgi Rodzaju, Komentarz słowny do Księgi Rodzaju), tłum. J. Sulowski, Warszawa 1980, s. 102 [PSP 25]).

40 Por. Aurelius Augustinus, De diversis quaestionibus LXXXIII 72, wersja polska: św. Augustyn, Księga osiemdziesięciu trzech kwestii, tłum. I. Radziejowska, Kęty 2012, s. 252-253 (Ad Fontes, 26).

41 Por. Aurelius Augustinus, De civitate Dei 22, 1, 1, wydanie polskie: Święty Augustyn, Państwo Boże, tłum. W. Kubicki, Kęty 1998, s. 906. 
ciało, które powstanie obleczone w nieskazitelność i nieśmiertelność" ${ }^{42}$. W niebie, dzięki wszechmocy Boga ludzie będą „przebywać w ciele” ${ }^{43}$. Wieczności będzie odpowiadała siódma epoka historii, co nawiązuje do ósmego dnia, który będzie wieczny ${ }^{44}$. Augustyn ujmuje zatem wieczność jako czas bez końca ${ }^{45}$.

Kolejnym autorem jest Boecjusz, który wychodząc od tezy, że Bóg jest wieczny ${ }^{46}$, objaśnia:

wieczność jest to więc jednocześnie całkowite i zarazem doskonałe posiadanie nieskończonego życia (,aeternitas igitur est interminabilis vitae tota simul et perfecta possessio"), co z porównania z rzeczami czasowymi jaśniej się uwypukli. Bo cokolwiek żyje w czasie, to jako teraźniejszość z przeszłości przesuwa się w przeszłość, i nie ma nic utworzonego w czasie, co by cały rozmiar swego życia jako równoczesność mogło objąć, ale tego, co jutrzejsze, jeszcze nie obejmuje, a to co wczorajsze, już utraciło; a w dzisiejszym życiu nie dłużej żyjecie, jak tylko w owym ruchomym i przelotnym momencie ${ }^{47}$.

Wieczność byłaby zatem kategorią bardziej jakości niż ilości istnienia, stanem zawsze aktualnej teraźniejszości i koegzystencji, wykluczającym wszelką sukcesję, zatem stanem różnym od nieograniczonej ciągłości czasu (perpetuitas, sempiternas), zupełnym i jednoczesnym posiadaniem całego istnienia ${ }^{48}$. Wieczność została tu określona jako „posiadanie

42 Por. Aurelius Augustinus, De civitate Dei 22, 21, s. 943.

43 Por. Aurelius Augustinus, De civitate Dei 22, 11, s. 932.

44 Aurelius Augustinus, De civitate Dei 22, 30, s. 967: „Ten siódmy okres to będzie nasz sabat, którego końcem nie będzie wieczór, lecz będzie dzień Pański, niby ósmy wieczny dzień, uświęcony zmartwychwstaniem Chrystusowym - niedziela, która jest proroczym obrazem (prefigurans) odpoczynku nie tylko ducha, lecz i ciała. Tam to odpoczywać będziemy i widzieć; widzieć i kochać; kochać i chwalić. Oto, co będzie na końcu bez końca. Jakiż bo inny jest nasz cel, jak nie ten jedyny, aby dojść do królestwa, które żadnego końca nie ma".

45 Por. A. Nitrola, Trattato di escatologia 2, s. 482-483.

46 Anicius Manlius Severinus Boethius, De consolatione philosophiae 5, 6: „Że Bóg jest wieczny, jest to wspólny sąd wszystkich istot obdarzonych rozumem" (wyd. polskie: Anicius Manlius Severinus Boethius, o pocieszeniu jakie daje filozofia, tłum. W. Olszewski, Warszawa 1962, s. 141 [Biblioteka Klasyków Filozofii, 68]).

47 Anicius Manlius Severinus Boethius, De consolatione philosophiae 5, 6, s. 141.

${ }_{48}$ Leon Joachimowicz w przypisie 20 przywoływanego powyżej traktatu Anicius Boethius, De consolatione philosophiae, s. 163-164, zauważył, że elementy definicji wieczności, jaką podał Boecjusz można odnaleźć w już platońskim Timajosie $37 \mathrm{DE}$, a wątki neoplatońskie u Proklosa Diadocha, Elementy teologii i u Plotyna, Enneady 3, 7, 3; 5, 1, 4. 
nieskończonego życia” (,aeternitas ... interminabilis vitae possessio”), gdzie „nieskończone” (interminabilis) nie oznacza zwyczajnie bez końca, ale bez ograniczenia w znaczeniu limitu (terminus). Czyli w jakimś sensie wieczność oznaczała także życie bez ograniczeń / limitów i była doskonałym posiadaniem takiego życia („,tota simul et perfecta possessio”) ${ }^{49}$. Boecjusz, wychodząc od rozważań Platona, z Timajosa 28nn i Politicus $273 \mathrm{E}$, gdzie ten przypisuje światu wieczność w sensie bezkresnego trwania w czasie, stwierdza:

Dlatego nie mają słuszności ci, którzy słysząc, że Platonowi świat ten widział się takim, jakoby ani nie miał w czasie początku, ani nie miał doznać w czasie końca (interminabilem), sądzą, jakoby w ten sposób świat stworzony był współwiecznym ze stwórcą. Co innego jest bowiem snuć się przez czasowo nieograniczone życie, co Platon przypisuje światu, a co innego objąć w posiadanie życie bez początku i bez końca (interminabilis) naraz jako cała teraźniejszość, co jest oczywiście właściwością istoty boskiego ducha. I nie należy sądzić, że Bóg jest dawniejszy od swego stworzenia rozciągłością czasu, lecz raczej właściwością swej jednolitej natury. Bo jedynie ten stan teraźniejszości nieruchomego życia ów nieskończony ruch rzeczy czasowych naśladuje, a gdy go nie może odtworzyć ani mu dorównać, $\mathrm{z}$ bezruchu w ruch wpada, $\mathrm{z}$ niezłożoności teraźniejszości (ex simplicitate praesentiae) przeradza się w nieskończoną rozciągłość (in infinitam quantitatem) przyszłości i przeszłości; a skoro całej pełni swego życia nie może jednocześnie posiadać, zatem już przez to samo, że w jakiś sposób nigdy nie przestaje być tą rzeczą, której wypełnić ani wyrazić nie może, zdaje się w pewnej mierze tę rzecz naśladować i stara się przywrzeć do jakiejkolwiek teraźniejszości tego znikomego i przelotnego momentu. [...] Jeżeli wiec chcemy nadać rzeczom właściwe nazwy, to idąc za Platonem nazwiemy Boga wiecznym (aeternum), a świat - ciągle trwającym (perpetuum) ${ }^{50}$.

Boecjusz przejmuje zatem od Platona przeciwstawienie wieczności czasowi, nieruchomości ruchowi, a przede wszystkim myśl, że świat jest obrazem modelu, a czas obrazem wieczności. Rozróżnienie pomiędzy wiecznością a ciągłym trwaniem potwierdza przedstawiane ujęcie na poziomie terminologicznym i wprowadza pomiędzy wieczność a czas ów trzeci wymiar trwania, którego jednak nie odnosi do tajemniczej przestrzeni, jak to czynił Platon, ale pośrednio nazywa go innym terminem, pochodzącym od czasownika być (ớí) ${ }^{51}$.

49 Por. A. Nitrola, Trattato di escatologia 2, s. 483.

50 Anicius Manlius Severinus Boethius, De consolatione philosophiae 5, 6, s. 141.

51 Por. A. Nitrola, Trattato di escatologia 2, s. 484. 


\section{Zakończenie}

Wszystkie analizowane metafory konceptualne wyrażają wiarę w życie wieczne. Zarówno w tekstach biblijnych, jak i w reprezentatywnych tekstach autorów patrystycznych Kościoła zachodniego są oddawane jako archetypy pozytywne. Zarówno metafory przestrzenne (raj, niebo), jak i metafory ontologiczne (wizja uszczęśliwiająca, życie wieczne) są wiodącymi schematami wyobrażeniowymi dotyczącymi miejsc nadprzyrodzonych czy cech tych miejsc. Metafory biblijne rozważane przez kolejnych ojców Kościoła zachodniego niewątpliwie tworzyły uniwersalny język chrześcijański, a przez swą elementarną obrazowość, bliską każdemu człowiekowi, angażowały wyobraźnię wiernych, wzbogacając uczuciowe reakcje czytelnika na przekaz teologiczny dotyczący tematyki nieba i wieczności. Nawet skrótowe omówienie wspomnianych eschatologicznych metafor konceptualnych związanych z niebem wskazuje na jedność i progresywny charakter chrześcijańskiej Tradycji teologicznej (np. obraz ogrodu Eden, przez obraz raju staje się ostatecznie obrazem nieba; czy obraz trwałości życia, który staje się obrazem życia wiecznego). Teksty zachodnich ojców Kościoła wykazują tu praktycznie zbieżność z wcześniejszym orędziem biblijnym. Znacząca w tym kontekście wydaje się uwaga Antonio Nitriola, że definicje dogmatyczne antyku czy średniowiecza są obciążone bagażem koncepcji i systemów, które chociaż wyrażają się przez metafory, często są to metafory nieuświadomione. Dlatego, odczytując je dzisiaj, musimy zdawać sobie sprawę z różnicy dyskursu analogicznego i opisów metaforycznych.

\section{Bibliografia}

\section{Źródła}

Anicius Boethius, De consolatione philosophiae; wydanie polskie: Anicius Manlius Severinus Boethius, O pocieszeniu jakie daje filozofia, tłum. W. Olszewski, Warszawa 1962 (Biblioteka Klasyków Filozofii, 68).

Aurelius Augustinus, De civitate Dei; wydanie polskie: Święty Augustyn, Państwo Boże, tłum. W. Kubicki, Kęty 1998.

Aurelius Augustinus, De diversis quaestionibus LXXXIII; wydanie polskie: Św. Augustyn, Księga osiemdziesięciu trzech kwestii, tłum. I. Radziejowska, Kęty 2012 (Ad Fontes 26). 
Aurelius Augustinus, De Trinitate; wydanie polskie: Św. Augustyn, O Trójcy Świętej, tłum. M. Stokowska, Kraków 1996 (Biblioteka Filozofii Religii, 30).

Aurelius Augustinus, Sermones; wydanie polskie: Św. Augustyn, Wybórmów: kazania świąteczne i okolicznościowe, tłum. J. Jaworski. Warszawa 1973 (PSP 12).

Aurelius Augustinus, De Genesi ad litteram imperfecus liber; wydanie polskie: Św. Augustyn, Pisma egzegetyczne przeciw manichejczykom (Przeciwko manichejczykom komentarz do Księgi Rodzaju, Niedokończony komentarz słowny do Ksiegi Rodzaju, Komentarz słowny do Księgi Rodzaju), tłum. J. Sulowski, Warszawa 1980, 83-112 (PSP 25).

Clemens Alexandrinus, Stromata, Paris 1951 (SCh, 30); wydanie polskie: Klemens Aleksandryjski, Kobierce zapisków filozoficznych dotyczących prawdziwej wiedzy, t. 1-2, tłum. J. Niemirska-Pliszczyńska, Warszawa 1994.

Gregorius Magnus, Moralia sive Expositio in Iob; wydanie polskie: św. Grzegorz Wielki, Moralia. Komentarz do Księgi Hioba, t. 2, tłum. K. Nastał, E. Buszewicz i in., Kraków 2006 (Źródła Monastyczne, 41).

Gregorius Magnus, Moralia sive Expositio in Iob; wydanie polskie: św. Grzegorz Wielki, Moralia. Komentarz do Ksiegi Hioba, t. 4, tłum. E. Buszewicz, A. Wilczyński, Kraków 2013 (Źródła Monastyczne, 63).

Irenaeus Lugdunensis, Adversus Haereses, ed. N. Brox, Freiburg im Breisgau 2001 (Fontes Christiani 8/5).

Teophilus Antiochenus, Ad Autolycum; wersja polska: Teofil z Antiochii, Do Autolika, tłum. L. Misiarczyk, Pierwsi apologeci greccy, Kraków 2004, s. 367-486 (Biblioteka Ojców Kościoła, 24).

\section{Bibliografia załącznikowa}

Barr J., Biblical Words for Time, London 1962 (Studies in Biblical Theology, 33).

Benveniste É., Il vocabolario delle istituzioni inodoeuropee, vol. 2: Potere, diritto, religio$n e$, Torino1981 (Nuova Biblioteca Scientifica Einaudi, 55bis).

Burton R.J., Heaven, Paradise, w: Augustine through the Ages. An Encyclopedia, ed. A.D. Fitzgerald, Grand Rapids (Michigan) 1999, s. 419-421.

Cremascoli G., Novissima hominis nei Dialogi di Gregorio Magno, Bologna 1979.

de la Peňa J.L.R., L'altra dimensione, Roma 1981.

Dubarle A-M., Oczekiwanie nieśmiertelności w Starym Testamencie i w judaizmie, tłum.

E. Szewc, „Concilium. Wydanie Polskie” 6-10 (1970), s. 214-222.

Dufour X.L., Wniebowstapienie, w: Stownik teologii biblijnej, tłum. K. Romaniuk, Poznań 1990, s. 1053-1068.

Gilson É., Introduzione allo studio di Sant'Agostino, Genova-Milano 2014.

Guitton J., Le temps et l'éternité chez Plotin et Saint Augustin, Paris 2004.

Haag E., Der Mensch am Anfang. Die alttestamentliche Paradiesvorstellung nach Gn 2-3, Trier 1970.

Jankowski A., Eschatologia Nowego Testamentu, Kraków 2007.

Kasprzak D., Drugi millenaryzm w ujęciu Wiktoryna z Poetovium, w: Między Biblią a kultura, red. T. Jelonek, R. Bogacz, Kraków 2011, s. 43-57 (Biblia w Kulturze Świata, 2). 
Kasprzak D., Kształtowanie się nauki o niebie w teologii patrystycznej I-III wieku, Kraków 2017.

Kasprzak D., Milenaryzm: „ziemski raj” tylko dla wybranych sprawiedliwych - okres patrystyczny, w: W oczekiwaniu na Królestwo. Nadzieje i obawy związane z końcem tysiąclecia, red. P.J. Śliwiński, Kraków 2000, s. 89-124.

Kobielus S., Człowiek i ogród rajski w kulturze religijnej średniowiecza, Warszawa 1977.

Krąpiec M.A., Zdybicka Z.J., Świętość spełnieniem osoby, w: Człowiek - kultura - uniwersytet, red. M.A. Krąpiec, Lublin 1982, s. 59-74.

Lakoff G., Johnson M., Metafory w naszym życiu, tłum. T. Krzeszowski, Warszawa 1988.

Lossky V., Vision de Dieu, Paris 1962.

Myszor W., Millenaryzm w ujęciu Ireneusza z Lyonu, „Tarnowskie Studia Teologiczne” 19 (2000) z. 1, s. 27-38.

Naumowicz C., Konstytucja Benedykta XII „Benedictus Deus”. Próba nowego spojrzenia na kontrowersję, „Teologia w Polsce” 4 (2010) nr 1, s. 109-123.

Nitrola A., Trattato di escatologia, vol. 2: Pensare la venuta del Signore, Cinisello Balsamo (Mi) 2010.

Pesch R., Il vangelo di Marco. Parte seconda. Testo e traduzione. Commento ai capp. 8,2716,20, Brescia 1982 (Commentario teologico del Nuovo Testamento, II/2).

Pietras H., Millenaryzm a interpretacja szabatu (I-II w.), „Tarnowskie Studia Teologiczne" 19 (2000) z. 1, s. 9-25.

Porter S.E., Wieczność, wieczny, w: W. Ralph, P. Martin, P.H. Davids, Słownik późnych ksiag Nowego Testamentu i pism Ojców apostolskich, tłum. zbiorowe, Warszawa 2014, s. 1064-1066 (Prymasowska Seria Biblijna, 39).

Rahner K., Visio beatifica, w: Enciclopedia teologica. Sacramentum mundi, vol. 8, ed. K. Rahner, Brescia 1977, s. 637-642.

Ryken L., Longman III T., Wilhoit J. C., Niebo, w: Słownik symboliki biblijnej. Obrazy, symbole, motywy, metafory, figury stylistyczne i gatunki literackie w Piśmie Świętym, tłum. Z. Kościuk, Warszawa 2003, s. 579-581 (Prymasowska Seria Biblijna, 20).

Schmaus M., Das Paradies, München1965.

Trottmann Ch., La vision béatifique des disputes scolastiques à sa définition par Benô̂ XII, Rome 1995.

Vorgrimler H., Geschichte des Paradies und des Himmels. Mit einem Exkurs über Utopie, München 2008.

Wojtczak J., Eschatologiczne koncepcje Laktancjusza w VII księdze „Divinae Institutiones”, „Vox Patrum” 19 (1990), s. 609-620.

Wysocki M., Eschatologia okresu prześladowań na podstawie pism Tertuliana i Cypriana, Lublin 2010. 